Parachin (2012)

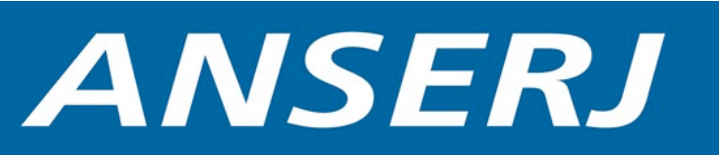

Vol. 3, No 1

Spring / Printemps, 2012

pp. $57-81$

Canadian Journal of Nonprofit and Social Economy Research

Revue canadienne de recherche sur les OBSL et I'économie sociale

\title{
Funding Charities Through Tax Law: When Should a Donation Qualify for Donation Incentives?
}

\author{
Adam Parachin \\ University of Western Ontario
}

\begin{abstract}
Canadian income tax law provides incentives for taxpayers to make charitable donations. Since only those donations to charities qualifying as charitable "gifts" are eligible for donation incentives, the definition of gift bodes significant revenue implications for charities and government alike. The Income Tax Act does not, however, define the term gift. The tests applied by courts and regulators to identify gifts in the absence of a statutory definition are contradictory, unnecessarily restrictive, and inconsistent with the tax policy behind donation incentives. The recent attempt to improve the law through the proposed "split-receipting" rules has achieved little in the way of meaningful reform. The ideal solution is to adopt a statutory definition of "charitable donation" that will both broaden and clarify the range of eligible donations.
\end{abstract}

\section{RÉSUMÉ}

La loi canadienne de l'impôt sur le revenu prévoit des incitatifs visant à encourager les contribuables à faire des dons. Étant donné que seuls les dons faits aux œuvres de bienfaisance qui se qualifient en tant que « dons » de bienfaisance peuvent donner droit à ces incitatifs, la définition du terme « don » est porteuse d'importantes répercussions fiscales, tant pour les organisations caritatives que pour le gouvernement. Toutefois, la Loi de l'impôt sur le revenu ne définit pas le terme " don ». Les critères appliqués par les cours et les autorités de réglementation pour identifier ce qui constitue un don, en l'absence d'une définition établie par la loi, sont contradictoires, inutilement restrictives et incohérentes avec la politique fiscale concernant les incitatifs accordés au titre des dons de bienfaisance. La récente tentative d'améliorer la loi avec les règles proposées sur le fractionnement des reçus n'a eu que peu de résultats pour mener à une réforme significative. La solution idéale est d'adopter une définition législative du terme « don » qui permettrait d'élargir et de clarifier la portée des dons admissibles.

Keywords / Mots clés : Charity; Gift; Donation; Tax; Incentive(s) / Charité; don; impôt; incitatif(s) 


\section{Parachin (2012)}

\section{INTRODUCTION}

Reform is coming to the tax rules governing charitable donations. The House of Commons Standing Committee on Finance has announced that it will study tax measures surrounding charitable giving in 2012. The study brings the prospect of much needed improvement to an underdeveloped aspect of tax policy. In thinking about reform options it is helpful to begin by identifying the three essential features of tax codes providing incentives for charitable gifts.

1. Eligible Donees: To what kinds of institutions must a taxpayer donate in order to qualify for a donation incentive?

2. Design Features of Donation Incentive: Should the incentive take the form of a tax deduction, tax credit, or matching state grant? If a credit, what should be the amount(s) of the credit? How, if at all, should capital gains tax apply to donations of capital property?

3. Eligible Contributions: What sorts of contributions to eligible donees should qualify for donation incentives?

A case could be made for reform in relation to each of these issues. The first issue-eligible donees-raises for consideration the legal definition of charity. Under the current provisions of the Income Tax Act' (the "ITA") a donation to a not-for-profit will be eligible for donation incentives only if the not-for-profit qualifies as a charity at common law. ${ }^{2}$ Most, if not all, analysts would agree that the common law definition of charity is an area where there is considerable room for improvement. However, this is a highly complex and politically sensitive issue of tax policy that should be studied as a discrete topic rather than as just one part of the Standing Committee's broader study of donation incentives.

The second issue-the design features of donations incentives-will very likely be the issue attracting the lion's share of attention. There are different statutory models for recognizing charitable donations. One model is where the state recognizes charitable donations through a matching state grant calculated as a percentage of each donation. The matching grant is delivered directly by the state to the charities to which donors contribute. The amount of the grant can correspond with the income taxes paid (or portion thereof) by the donor on the amount donated. ${ }^{3}$ Another model is where the state reduces the after-tax cost of donations through income tax concessions for qualifying contributions to charities. Under this model, state subsidization for charities is delivered to donors in the form of tax relief rather than to charities in the form of matching grants. Under both models, each dollar allocated to charities through donations costs donors a lesser amount.

\footnotetext{
${ }^{1}$ RSC 1985, c. 1 (5th Supp.), as amended.

${ }^{2}$ For the most recent Supreme Court of Canada decision on point, see Amateur Youth Soccer Association v. Canada Revenue Agency [2007] S.C.J. No. 42.

${ }^{3}$ This model has been adopted in England through the "Gift Aid" program. The program allows charities to recover from the state the basic rate of tax (20\%) paid by donors on qualifying donations. For example, a $£ 100$ qualifying donation made by a donor out of after-tax income corresponds with $£ 125$ gross income (assuming a basic tax rate of $20 \%$ ). The charitable donee is able to recover the $£ 25$ tax paid by the donor under the Gift Aid program. Donors with a higher tax rate can themselves recover taxes paid beyond the basic rate of $20 \%$. For an accessible summary of the rules, see Picarda H. (2010). The Law and Practice Relating to Charities. $4^{\text {th }}$ ed. West Sussex, Bloomsbury Professional Ltd (1014-1029).
} 


\section{Parachin (2012)}

The Canadian system is based on the latter of the two models, that is, it involves the use of tax incentives to reduce the after-tax cost of donations. This is achieved through a two-stage tax credit for individuals, ${ }^{4}$ a deduction for corporations,${ }^{5}$ and a capital gains tax exemption for donations of publicly traded securities and ecological property. ${ }^{6}$ There does not appear to be a vocal lobby in favour of a matching grant system being adopted in Canada. Instead, as soon it appeared that a window of opportunity for reform was opening, sector activists began advocating in favour of a new "stretch tax credit" and of exempting donations of land and private securities from capital gains tax. ${ }^{7}$ Such newsworthy reform proposals may have an appeal to media savvy politicians concerned as much with headlines and sound bites as with actual improvement of the law.

But it is the third issue-eligible contributions-where there exists the greatest prospect of meaningful and achievable, though less newsworthy, reform. While the ITA provides that only those contributions to charities qualifying as charitable gifts are eligible for donation incentives, it does not define the term "gift."8 There exists a vast body of cases and regulatory publications dealing with the meaning of gift but the authorities have not produced a test for identifying charitable gift transactions that is sufficiently clear or well-developed for planning purposes. ${ }^{9}$ In fact, it is impossible to succinctly state how "charitable gift" has been defined in the tax precedents without acknowledging a number of bewildering and seemingly unprincipled qualifications. The authorities have tended to require that donations meet criteria that lack any apparent policy relevance, including requirements pertaining to voluntariness and motive. There has been a pronounced tendency in the authorities to focus on the legal form of donations and to ignore or downplay economic substance. For example, donations have been disqualified as charitable gifts where the donor was inspired by non-altruistic motives or where the donation arrangement was involuntary in the sense that it was legally enforceable, e.g., a transfer of property to charity by way of enforceable contract. The legal tests developed to identify donations qualifying as "charitable gifts" have seemingly been developed without adequate regard to the reasons why donation incentives exist in the first place. The ultimate purpose of donation incentives is to generate revenues for charities. The tendency of the authorities to focus on issues unrelated to this policy goal has resulted in many donation arrangements going unrecognized by income tax law (i.e., taxpayers involved are unable to access concessionary tax treatment) notwithstanding that the arrangements enhance the economic capacity of charities to deliver charitable goods and services.

\footnotetext{
${ }^{4}$ For the first $\$ 200$ of charitable gifts, the credit is calculated using the lowest marginal tax rate of $15 \%$. Once the $\$ 200$ threshold is crossed, the credit is calculated using the highest marginal tax rate of $29 \%$. See subsections 117(2) and 118.1(3) of the ITA.

${ }^{5}$ See paragraph 110.1(1)(a) of the ITA.

${ }^{6}$ See paragraphs $38($ a.1) and (a.2) of the ITA, respectively.

${ }^{7}$ For submissions to the Standing Committee go to: http://www.parl.gc.ca/HousePublications/Publication.aspx?DocId=5340612 $\&$ Language $=\mathrm{E} \&$ Mode $=1 \&$ Parl $=41 \&$ Ses $=1$ [May 22, 2012].

${ }^{8}$ See sections 118.1 and 110.1 and paragraphs 38(a.1) and (a.2) of the ITA. Note, though, that donations made by businesses may be deducted under paragraph 18(1)(a) of the ITA even if they do not qualify as gifts provided they were made for the purpose of producing income. In some respects, deductibility as a business expense is preferable because it is subject to neither annual donation limits nor to the under-developed case law and regulatory publications dealing with the meaning of charitable "gift." Charitable gifts by businesses will therefore be under-reported to the extent they are booked for tax purposes as business expenses rather than charitable donations. Courts have never squarely addressed specifically what differentiates the true charitable gift from the donation made as a business expense. The leading cases are Olympia Floor \& Wall Tile Co. (Quebec) Ltd. v. M.N.R., [1970] CTC 99 and Impenco Ltd. v. M.N.R., [1988] 1 CTC 2339.

${ }^{9}$ For a more detailed discussion of this point see Parachin A. (2009). Reforming the meaning of 'charitable gift: The case for an alternative to split receipting. Canadian Tax Journal, 57(4), 787.
} 


\section{Parachin (2012)}

A well-known example is that of the donor who sells property with an undisputed value of, say, $\$ 100,000$ to a charity for $\$ 5,000$. Since this is the economic equivalent of a $\$ 95,000$ cash donation, one might have assumed that income tax law would unreservedly recognize this as a $\$ 95,000$ charitable gift. Nevertheless, many authorities have concluded that these kinds of arrangements fail to qualify as charitable gifts for income tax purposes on the basis that, although they are gift-like in substance, they are in the legal form of a contractual quid pro quo. There are many other examples (see the section on current law and regulatory practice below) of donation arrangements that go unrecognized by income tax law even though they achieve the ultimate goals of donation incentives. Amendments to the ITA introduced in 2002-the split-receipting rules-were meant to remedy some of the inconsistency and incoherence in the law. However, these rules (yet to be enacted) represent only a modest improvement to the law.

This article builds a case for adopting a new approach to identifying eligible donations. Specifically, the author argues that a preferred approach to identifying eligible contributions would be to adopt a statutory definition of "charitable donation." The proposed definition is defined to include any transfer of property to or for the benefit of a charity whether by way of common law gift, trust, sale, or any other form of transaction. This definition would broaden the range of contributions that qualify for donation incentives, potentially generate new revenues for charities, and significantly simplify the law, all while reducing administrative compliance costs for charities. The argument is developed on the basis of a literature review and case law and policy analysis.

The case for reform will be developed in five steps. The first step is to situate the topic within a thematic framework. The second step is to review the tax literature to identify the theoretical underpinnings of tax concessions for charitable donations. The third step is to distil from this theoretical framework a set of considerations relevant to identifying the range of donations that should in theory qualify for donation incentives. The fourth step is to perform a case law analysis to illustrate the key ways in which current law and regulatory practice fixates on largely irrelevant considerations. The final step is to develop a concrete reform proposal capable of remedying the doctrinal and theoretical incoherence of current law.

\section{Thematic dimensions}

Before proceeding it is helpful to situate the topic within a thematic framework. Why does the approach taken by the law to identifying donations eligible for donation incentives matter? The most obvious reason is that this bodes potential revenue implications for charities. The impact of donation incentives on donors has been widely studied. ${ }^{10}$ It is generally accepted that donation incentives attract donations that would not otherwise be made. For example, based on their exhaustive study, Peloza and Steel conclude as follows: ${ }^{11}$

In general, our results support the hypothesis that tax deductions for charitable giving are treasury efficient. That is, on average, a decrease in $\$ 1$ in the cost of giving can be expected to result in more than $\$ 1$ being donated to charity through personal philanthropy.

Nevertheless, Peloza and Steel acknowledge that donors do not report tax incentives as the leading motivator to donate. This is consistent with the findings of the Canada Survey of Giving, Volunteering and Participating (CSGVP). The 2007 CSGVP Highlights Report provides that tax concessions ranked as the lowest reported motivation to give, with just $23 \%$ of respondents citing tax considerations as a reason to make a charitable

\footnotetext{
${ }^{10}$ For the groundbreaking study see Clotfelter C. (1985). Federal tax policy and charitable giving. Chicago: University of Chicago Press. For a more recent meta-analysis of the extensive published literature, see Peloza J. and Steel P. (2005). The price elasticities of charitable contributions: A meta-analysis. Journal of Public Policy and Marketing, 24(2) 260.

${ }^{11}$ Peloza and Steel, ibid, at 267.
} 


\section{Parachin (2012)}

donation. ${ }^{12}$ However, the percentage of donors identifying tax concessions as a motivation to donate has been steadily increasing. The 2004 CSGVP Highlights Report found that only $20 \%$ of respondents identified tax concessions as a motivation to donate..$^{13}$ The 2000 National Survey of Giving, Volunteering, and Participating found that only $13 \%$ of respondents identified tax concessions as a motivator, which the report noted was up from only $11 \%$ in the 1997 survey. ${ }^{14}$ So it would appear that qualifying for donation tax concessions is becoming an increasingly important issue for donors.

Since the non-recognition of certain donation arrangements removes the incentive for donors to participate in such arrangements, rational donors can be anticipated to restructure their planned donations so as to qualify for donation incentives, not donate at all, or not donate as much. So all else remaining equal, a broad and inclusive approach to identifying eligible donations has the potential to induce greater levels of giving than does a narrow approach.

The corollary of this is that the approach taken to identify eligible donations bodes revenue implications not just for charities but governments as well. It is generally (though not universally) accepted that the income tax recognition of charitable donations represents a tax expenditure-a form of government spending delivered through income tax law. As a result, a significant concern for policymakers is whether donation incentives are treasury efficient. Treasury efficiency requires that the amount of donations attracted by donation incentives is at least equal to the amount of foregone tax revenue. Many studies suggest that donation incentives are indeed treasury efficient but at least some have suggested otherwise..$^{15}$

The alleged inefficiency of donation incentives has been cited as one reason why such incentives should be altogether repealed, rather than reformed as recommended here. ${ }^{16}$ Even accepting that donation incentives are inefficient does not, however, follow that they should be repealed. To say that a donation incentive is inefficient is simply to observe that it would be comparably more efficient for the government to fund charities through a direct subsidy rather than indirectly through a donation incentive. An inefficient donation incentive could still be defended on the ground that it yields benefits (discussed in the section on theoretical underpinnings of donation incentives below) not available under a direct subsidy model. Be that as it may, concerns about economizing the fiscal consequences of donation incentives have played a role (mainly on an implicit level) in shaping how courts and regulators have defined charitable "gift."

However, the theme playing the most pronounced role in this article follows from the idea that donation incentives represent one of the key ways in which the law sets charities apart for privileged treatment. While both charities and non-charitable not-for-profits are generally exempt from income tax, the distinguishing tax characteristic of charities is that only donations to charities are eligible for donation incentives. So without losing sight of the revenue dimensions of the topic (for both charities and government alike), it is important to carefully

\footnotetext{
${ }^{12}$ Hall M., Lasby D., Ayer S., and Gibbons W.D. (2009). Caring Canadians, involved Canadians: Highlights from the 2007 Canada survey of giving, volunteering and participating. URL:

http://www.givingandvolunteering.ca/files/giving/en/csgvp_highlights_2007.pdf [April 13, 2012].

${ }^{13}$ Hall M., Lasby D., Gumulka G., and Tryon C. (2006). Caring Canadians, involved Canadians: Highlights from the 2004 Canada survey of giving, volunteering and participating. URL:

http://www.givingandvolunteering.ca/files/giving/en/csgvp_highlights_2004_en.pdf [April 13, 2012].

${ }^{14}$ Hall, M., McKeown L., and Roberts K. (2000). Caring Canadians, Involved Canadians: Highlights from the 2000

National Survey of Giving, Volunteering and Participating. URL:

http://www.givingandvolunteering.ca/files/giving/en/rp_2000_nsgvp_highlights.pdf [April 13, 2012].

15 See Peloza and Steel supra note 10.

${ }^{16}$ See Brooks N. (2001). The tax credit for charitable contributions: Giving credit where none is due. In J. Phillips, B. Chapman and D. Stevens, (eds.), Between state and market: Essays on charities law and policy in Canada (p. 457)

Kingston: McGill-Queen's University Press.
} 


\section{Parachin (2012)}

consider whether the tax policy goals behind privileging charities via donation incentives are being frustrated by the approach taken to identify eligible donations.

\section{Theoretical underpinnings of donation incentives}

The reasons why tax concessions exist for charitable donations provide some helpful clues about how eligible donations should be identified. It was observed in 1972 that the theoretical foundation behind donation incentives had been so extensively debated that it was questionable "whether anything new remains to be said." ${ }^{17}$ Nevertheless, the matter is still being debated. A review of the literature reveals two competing theoretical frameworks: tax base theories and subsidy theories.

\section{Tax base theories}

The essential argument of tax base theorists is that income tax should only be applied to that which is truly "income" and thus within the normative tax base (the base against which income tax is applied). Any tax provision exempting from taxation that which is not properly construed as income in the first place is not a subsidy or tax expenditure but rather a structural income defining provision serving a discrete income tax purpose (namely, the proper measurement of taxable income). Relying upon normative conceptions of income that exclude charitable donations, tax base theorists contend that charitable donations are not income and are thus not properly subject to income tax. It should be apparent from this that tax base theorists draw upon tax logic rather than the inherent goodness of charitable works to justify the income tax recognition of charitable donations. ${ }^{18}$ As one tax base theorist put it, the income tax recognition of donations represents a "refinement in our notion of an ideal personal income tax, rather than a departure from it." 19

Tax base theories have attracted sustained and intense criticism in the income tax literature. ${ }^{20}$ For present purposes, there is little to be gained from delving into these criticisms as there is an uncontroversial basis on which to conclude that the tax base theories lack force, at least in Canada. There is something to be said for tax base theories in jurisdictions recognizing charitable donations through a tax deduction: if charitable donations are not truly income, it follows that they should be deducted from gross income to properly calculate taxable income. But in Canada charitable donations-at least those made by individuals-are not dealt with via a deduction but rather a two-stage tax credit.21 The credit operates such that for the first $\$ 200$ of charitable donations, many donors (in fact all donors except for those in the lowest marginal tax bracket and those with no taxable income) pay more income tax on donated amounts than what they receive back in the form of a tax credit. Conversely, for donations in excess of $\$ 200$, all donors except for those in the highest marginal tax bracket receive a tax credit that is greater than the taxes owing on donated amounts. The credit would not be structured in this manner, if, as tax base theorists claim, the issue was simply one of ensuring that taxes

\footnotetext{
${ }^{17}$ Bittker B. (1972-1973). Charitable contributions: Tax deductions or matching grants? Tax Law Review, 28,37 at 37.

${ }^{18} \mathrm{Or}$ at least they purport to rely upon tax logic. One of the criticisms of tax base theories is that they rely upon considerations extrinsic to tax to justify the exclusion of charitable donations from the tax base. See, for example, Gergen (1988). The case for a charitable contributions deduction. Virginia Law Review, 74, 1416.

${ }^{19}$ Andrews W. (1972). Personal deductions in an ideal income tax. Harvard Law Review, 86, 309 at 312. See also Buckles J.R. (2005). The community income theory of the charitable contributions deduction. Indiana Law Journal, 80(4) 947 and Bittker, supra note 17.

${ }^{20}$ For a review of the criticisms, see Parachin, supra note 9.

${ }^{21}$ For an analysis of the credit, see Duff D. (2001). Charitable contributions and the personal income tax: Evaluating the Canadian credit. In J. Phillips, B. Chapman and D. Stevens, (eds.), Between state and market: Essays on charities law and policy in Canada (p. 407). Kingston: McGill-Queen's University Press.
} 


\section{Parachin (2012)}

owing correspond with taxable income. ${ }^{22}$ Indeed, the charitable tax credit could only be justified consistently with tax base theories if it operated like a tax deduction such that the value of the credit corresponded with the taxes owing on donated amounts.

\section{Subsidy theories}

The prevailing view is that donation incentives should be understood not as a matter of the proper definition of income but rather as a state subsidy for charities delivered through tax law. ${ }^{23}$ Subsidy theorists contend that a state subsidy of charity is justifiable on the ground that charities perform good works and would otherwise be underfunded due to market failure. Specifically, the inability of charities to generate or distribute profits to investors (the "non-distribution constraint," as its known) and vulnerability to free-riding (the consumption of charitable goods and services without contribution) would result in charities otherwise being chronically underfunded. ${ }^{24}$ The government could subsidize charities through a direct transfer but subsidy theorists contend that tax concessions reducing the after-tax cost of charitable donations is the preferred funding model. However there is disagreement as to why this is the case.

One line of argument contends that charities relieve the government of expenses that it would otherwise have to incur. ${ }^{25}$ In this view, tax concessions for charitable donations can be defended on efficiency grounds provided the amount of donations they induce outweighs the amount of tax revenues they cost.26 Of course, this efficiency advantage might be lost once cumulative fundraising and charitable administration costs are compared to government administration costs. Another line of argument contends that a donation incentive results in a greater quality of goods and services than would a direct subsidy because it fosters heightened competition among charities for donations. ${ }^{27}$ Similarly, a donation incentive has been said to achieve a more diverse array of charitable goods and services because charities will provide goods or services even where there is insufficient demand to influence elected legislatures, provided there is at least sufficient demand to attract donations. ${ }^{28}$ Also, some charitable purposes pertaining to the advancement of religion are not exactly ideal candidates for direct state funding. Such purposes can therefore only be subsidized—if at all—by the state indirectly. ${ }^{29}$

\footnotetext{
${ }^{22}$ For a similar observation, see Edgar T. (1997). The concept of taxable consumption and the deductibility of expenses under an ideal personal income tax base. In R. Krever, (ed.), Tax conversations: A guide to the key issues in the tax reform debate (p. 293 at 343 and 349). London: Kluwer Law International.

${ }^{23}$ Colombo describes this as "the most widely accepted rationale." See Colombo J.D. (2001). The marketing of philanthropy and the charitable contributions deduction: Integrating theories for the deduction and tax exemption" Wake Forest Law Review, 36, 657 at 682.

${ }^{24}$ See Colombo, ibid., for a review of the relevant literature.

${ }^{25}$ See, for example, Pozen D. (2006-2007). Remapping the charitable deduction. Connecticut Law Review, 39, 531 at 556.

${ }^{26}$ See, for example, Vickrey W. (1962). One economist's view of philanthropy. In F.G. Dickinson, (ed.), Philanthropy and Public Policy (p. 31) New York: National Bureau of Economic Research; Feldstein M. (1975). The income tax and charitable contributions. National Tax Journal, 28, 81; Gergen, supra note 18, at 1404; Wiedenbeck P. (1985). Charitable contributions: A policy perspective. Missouri Law Review, 50:1, 85; Colombo, supra note 23 at 683; Duff D. (2004). Tax treatment of charitable contributions in Canada: Theory, practice, and reform. Osgoode Hall Law Journal, 42, 47 at 59-61.

${ }^{27}$ Levmore S. (1998). Taxes as ballots. University of Chicago Law Review, 65, 387 at 411.

${ }^{28}$ See, for example, Weisbrod B. (1975). Toward a theory of the voluntary non-profit sector in a three-sector economy. In E. Phelps (ed.), Altruism, morality, and economic theory (p. 171). New York: Russell Sage Foundation.

${ }^{29}$ See, for example, Gergen, supra note 18, at 1434-1443 and Pozen, supra note 25, at 559. However, not everyone agrees that it is proper for the state to even indirectly subsidize religious activity. See, for example, Brooks, supra note 16, at 480.
} 


\section{Parachin (2012)}

Another line of reasoning contends that donation incentives foster enhanced pluralism, innovation, and civic engagement. ${ }^{30}$ Consistent with this view, donation incentives have been defended on the ground that they represent a form of direct democracy, that they allow donors to vote via charitable donations how public funds are allocated. ${ }^{31}$ The essential idea is that donation incentives constitute a "social choice mechanism to determine government spending" 32 through which the state becomes a "financing partner"33 of charitable donors.

Yet another argument is that tax concessions for donations are superior to direct government grants in terms of cost allocation ${ }^{34} \mathrm{~A}$ direct grant would allocate the cost of a particular program across all taxpayers equally without making any adjustment for any individual taxpayer's preferences ${ }^{35}$ Inevitably this would result in some taxpayers over-contributing to charities they do not wish to support or under-contributing to charities whose goods and services they consume. But when an individual donor makes a charitable donation, the cost of the donation is shared by taxpayers generally only to the extent of the tax credit available to the donor. Even with this cost sharing, it remains the case that the donor makes a bigger donation to the charity than any other single taxpayer. This is desirable because it better allocates the cost of specific charitable programs to the specific taxpayers who value them enough to make donations than would a direct grant.

Of course, not everyone agrees that it is appropriate for the state to subsidize charities via tax concessions for charitable donations. This funding model has been criticized on the basis that it is inefficient, ${ }^{36}$ lacks the transparency and control of direct government spending, ${ }^{37}$ and unfairly grants wealthy philanthropists a disproportionate say in the distribution of public funds ${ }^{38}$ Others deny on philosophical grounds the usefulness of understanding tax concessions for donations as an attempt to remedy market failure. ${ }^{39}$ But these criticisms of subsidy theory do not discredit the foundational claim advanced by subsidy theorists that tax concessions for charitable donations are ultimately a tool to help finance charities. They reflect a broader debate over how and why charities should be funded rather than a fundamental denial that subsidizing charities is the ultimate goal of donation incentives.

\section{Defining eligible donations in light of underlying theory}

Having established that the policy function of donation incentives is simply to help finance charities, it is now possible to identify a theoretically sound approach to identifying eligible donations. If donation incentives are really just a way of economically equipping charities to perform charitable works (as opposed to, say, properly measuring the taxable "income" of charitable donors) it follows that all contributions to charities achieving this

\footnotetext{
${ }^{30}$ See Duff, supra note 26, at 62 . Bittker was an early proponent of the view that tax concessions for charitable gifts

foster democratic renewal. See Bittker, supra note 17, at 61-62.

${ }^{31}$ See Levmore, supra note 27.

32 Ibid., at 405.

${ }^{33}$ Ibid., at 388 .

${ }^{34}$ Gergen, supra note 18 , at 1399-1406.

${ }^{35}$ See ibid., at 1402 .

${ }^{36}$ See, for example, Brooks, supra note 16 , at 472.

${ }^{37}$ See Duff, supra note 26, at 61; Pozen, supra note 25, at 553-55; Brooks, supra note 16, at 469-71. More generally, see Surrey S. (1973). Pathways to tax reform: The concept of tax expenditures. Cambridge, Mass.: Harvard University Press.

${ }^{38}$ See, for example, Brooks, supra note 16, at 459-462. Not everyone agrees on this point. If the tax concessions for charitable gifts are meant to serve as an incentive for giving, then it may make some sense to provide the greatest incentive to those - the wealthy - with the most to give. See Colombo, supra note 23, at 684 and the sources cited therein.

${ }^{39}$ Stevens D. (2000). Rescuing Charity. In C. Mitchell and S. Moody (eds.) Foundations of charity (29 at 49-51). Portland: Hart Publishing.
} 


\section{Parachin (2012)}

basic goal should (at least as a starting point for analysis) qualify for donation incentives. In this view, a charitable gift is any transfer to a charity that confers net value on the charity. It should not matter whether the donor receives consideration for the donation, whether the donor's motive was truly charitable, whether the donation is structured in the legal form of a common law gift or some other legal form, such as a contract, trust, or interest free loan, or whether the donation meets any one of a number of other specious tests applied under current law and regulatory practice to identify eligible donations. The ultimate question to ask of a putative charitable gift is simply whether it to some measurable extent economically equips a charity to achieve its charitable mission. If a donation meets this essential standard then it is consistent with the basic purpose of donation incentives and, subject to certain exclusions we might devise, should be eligible for such incentives.

The donation arrangements meeting this standard include traditional cash donations but also a variety of other arrangements as well. This includes (but is not limited to) selling property to a charity for below fair market value consideration, purchasing property from a charity for an amount in excess of fair market value consideration, making a loan to a charity for either no interest or at a favourable interest rate, forgiving a debt owed by a charity, establishing a trust in which a charity is given a beneficial interest in the trust income and/or capital, allowing a charity to occupy land or to make use of a chattel for no consideration, incurring expenses on behalf of a charity, and making payment to a creditor as the guarantor of a debt obligation in respect of which a charity defaults. These arrangements vary in many respects but they share a common economic substance in that each of them entails a taxpayer taking steps to economically enable a charity to carry out its charitable purposes. All transactions with charities in which this occurs achieve the basic goals of donation incentives and should therefore be recognized as charitable gifts. The amount of the gift for which a donation receipt could be issued should correspond with the extent to which a transaction confers a net enrichment on a charity. ${ }^{40}$

In terms of possible exclusions, the donation of services is a likely candidate. The authorities have to date consistently concluded that donations of services do not qualify as gifts. ${ }^{41}$ If we accept that the tax policy objective of donation incentives is to help subsidize charitable works, there is no theoretical reason why the nonrecognition of donations of services need continue, since donated services are like donated property in that both kinds of donations help charities achieve their charitable purposes. ${ }^{42}$ However, there are persuasive reasons why the donation of services should continue to go unrecognized. One of the primary concerns is that donation arrangements involving services would be exceptionally difficult to value and audit. Further, the recognition of donated services could have potentially significant revenue implications for the government, which may be reason enough to continue their non-recognition given the current fiscal environment.

Other candidates for exclusion include donation arrangements in which a charity is enriched but the donor is not impoverished (either not at all or by an amount that is less than the amount by which the charity is enriched). In most cases an enrichment of the charitable donee will necessarily result in an equivalent impoverishment of the donor. A $\$ 500$ cash gift enriches the charity by $\$ 500$ and impoverishes the donor by the same amount. Likewise, a sale of property worth $\$ 100,000$ to a charity for $\$ 40,000$ both enriches the charity and impoverishes

\footnotetext{
${ }^{40}$ One possible exception is for donations where the degree of enrichment conferred on the charity is greater than the degree to which the donor is impoverished. There is at least a case for restricting the value of the gift to the degree of donor impoverishment in some circumstances (discussed below).

${ }^{41}$ The authorities on this point are innumerable. One of the leading decisions is Slobodrian v. R. [1998]. 3 C.T.C. 2654 (TCC).

${ }^{42}$ For an argument that donations of services should be recognized, see Duff, "Tax Treatment," supra note 26 at 66 and 96 and McDaniel P. (1972). Federal matching grants for charitable contributions: A substitute for the income tax deductions. Tax Law Review, 27, 377 at 396.
} 


\section{Parachin (2012)}

the donor by $\$ 60,000$. However, it is possible in select instances for a donation to enrich a charity but not impoverish the donor by an equivalent amount or to possibly even enrich both the charity and the donor.

Abusive gift schemes provide an example. These schemes can create a disparity between the charity's enrichment and the donor's impoverishment in part because portions of donations are often circulated back to donors through complex and artificial structures. A hallmark feature of abusive schemes is that they generate a positive cash flow for donors. ${ }^{43}$ However, there can also be non-abusive arrangements where this can occur. The Canada Revenue Agency (CRA) has considered an arrangement in which a newspaper offered free advertising space to persons who donated to charity. The charity would be enriched by an amount equal to the face value of the donation, but the donor would be impoverished by a lesser amount and perhaps not at all (the amount donated less the fair market value of the advertising space). The CRA concluded that the arrangement was not eligible for donation incentives because of the receipt of the benefit from a third party. ${ }^{44}$ Another example is that of a developer who was enriched when a donation of land to an educational charity had the effect of increasing the value of neighbouring land also held by the developer. A United States court concluded that the gain to the donor in these circumstances precluded the arrangement from qualifying for donation incentives. ${ }^{45}$ Many other authorities have categorically stated that donor impoverishment is an essential element of a charitable gift transaction. 46

One argument in favour of a donor impoverishment requirement is that it is inefficient and redundant to incentivize donations lacking the impoverishment of the donor. If a donation is going to enrich a donor, the enrichment itself represents a far better incentive to donate than any tax concession, or so the argument would go. If such donations are going to be made even without a tax incentive, some might say that their recognition is both unnecessary and inefficient. ${ }^{47}$

Also, certain policy goals behind donation incentives could be undermined through the income tax recognition of profitable donations. Recall from above that one argument in favour of donation incentives is that they allow donors to essentially vote how public funds are allocated. To the extent that a donor is not impoverished by a donation that donor's vote is free. This detracts from the desirability of allowing donors to allocate public funds through charitable gifts because donors may well take their votes less seriously to the extent that the votes are costless. ${ }^{48}$ Recall also that, according to subsidy theorists, the tax concessions for charitable gifts better allocate the costs of a given charitable program to donors who value that program than would a direct state subsidy. The desired cost allocation is disrupted where a donor is enriched by a donation.

\footnotetext{
${ }^{43}$ For a discussion of the common characteristics of abusive donation schemes, see Edgar and Sandler (2003). The tax expenditure program for charitable giving: Kicking a gift horse in the teeth. Canadian Tax Journal, 51:6, 2193.

${ }^{44}$ CRA document no. 2000-0053175, February 21, 2001. However, in CRA document no. 2000-0051255, February 13 , 2001, CRA opined that an incentive from a third party does not vitiate a gift provided that the incentive is available both to those who merely consider making gifts and those who actually make gifts. The two documents, written a week apart, are not altogether consistent.

${ }^{45}$ Ottawa Silica Company v. The United States (1983) 699 F.2d 1124.

${ }^{46}$ Most (though not all) of the contexts in which such statements are made involve abusive or sham donation arrangements. See, for example, McPherson v. R., [2007] 2 CTC 2277; Merhi c. R. [2001] 3 C.T.C. 2361 (TCC); Plante c. R. [1999] 2 C.T.C. 2631; CRA document no. 2003-0014695, November 18, 2003.

${ }^{47}$ Colombo makes a similar point in relation to what he describes as donations not vulnerable to free-riding. See supra, note 23 at 699 .

${ }^{48}$ Levmore, supra note 27 at 411.
} 


\section{Parachin (2012)}

Further, a donor impoverishment requirement could be defended on the ground that it provides the ultimate safety valve for the non-recognition of abusive donation schemes. If all else fails, an abusive donation could always be disallowed on the ground that the donor was enriched rather than impoverished. In fact this has been the primary function served by the donor impoverishment criterion in the precedents to date..$^{49}$

However, there are sound reasons to refrain from adopting as a categorical rule the idea that eligible donations must necessarily impoverish donors. The regulatory challenges posed by abusive donation arrangements reflect a poor basis on which to require all donations (abusive and non-abusive) to meet a donor impoverishment standard. As some of the examples above illustrate, not all donations failing a donor impoverishment standard are abusive. The better regulatory response to abusive donation arrangements is to enact specific antiavoidance provisions targeting these transactions on the basis of characteristics exclusive to this transaction type. ${ }^{50}$

Further, it is not necessarily the case that it would be inefficient for tax law to recognize donations that end up being profitable for donors. Much depends upon the circumstance. Concerns over the redundancy and inefficiency of tax concessions have the greatest resonance where a third party promises a direct pecuniary incentive to induce a donor to make a donation (such as the above example of the newspaper providing free advertising space to donors). However, even in this context the concerns raised are arguably best dealt with not by a rule that outright prohibits the recognition of a donation, but rather by the approach taken to valuing the donation. Provided that the value of the donation is calculated by deducting the value of the third party pecuniary incentive from the value of the donor's contribution to the charity, there is no sound reason why such arrangements should go unrecognized. ${ }^{51}$

In other contexts there is an argument for simply ignoring the enrichment of the donor and recognizing the donation at its face value. The idea that a tax incentive is inefficient, redundant, or somehow inconsistent with the tax policy behind donation incentives in circumstances where the donor is enriched by a donation breaks down where the enrichment is the fortuitous result of market forces. The above example of the land developer donating land to an educational charity illustrates the point. It is only with the benefit of hindsight that we can say that the donation was profitable to the donor and that therefore no tax incentive is necessary or desirable. However, it might make more sense to view such donations prospectively rather than retrospectively. At the time of the donation, the prospect that market forces might operate to yield a benefit to the donor (by increasing the value of neighbouring land held by the donor) is speculative. In this way, such an arrangement is distinct from a direct pecuniary incentive to donate promised by a third party. In this kind of a situation it is not at all obvious that the eventual enrichment of the donor detracts in any way from the policy goals of donation incentives.

\section{Current law and regulatory practice}

It was argued above that the only issue that ultimately matters when it comes to identifying whether a donation qualifies as a charitable gift for purposes of income tax law is whether it economically enriches a charity to some measurable extent. Nevertheless, the authorities have concluded (not always consistently) that many donation arrangements meeting this essential standard do not qualify as charitable gifts for tax purposes. Examples of

\footnotetext{
${ }^{49}$ See, for example, the authorities cited in supra note 46 .

${ }^{50}$ This point is discussed in greater detail below in the section "New definition of "charitable donation"” below.

${ }^{51}$ Even this might be going too far since it effectively diminishes the ability of third parties to supplement tax incentives with further pecuniary incentives to donate. Since higher levels of giving might follow if tax incentives are combined with third party incentives, there is a case for simply ignoring third party pecuniary incentives.
} 


\section{Parachin (2012)}

donations that have surprisingly been altogether excluded from the definition of gift or treated inconsistently in the authorities include instances in which donors have incurred expenses on behalf of charities, 52 forgiven debts owed by charities, ${ }^{33}$ donated the temporary use of property, ${ }^{54}$ sold property to charities for less than fair market value consideration, ${ }^{55}$ purchased property from charities for a value in excess of fair market value consideration, ${ }^{56}$ donated a form of property other than ownership, ${ }^{57}$ donated in fulfilment of a legal or moral obligation, ${ }^{58}$ donated for non-altruistic reasons, ${ }^{59}$ issued shares or stock options to a charity, ${ }^{60}$ donated further to negotiated litigation settlements ${ }^{61}$ and where estate beneficiaries have agreed under seal with the testator to donate a portion of their inheritance to charity. ${ }^{62}$ For a period of time the payment of insurance or Registered Retirement Savings Plan (RRSP) proceeds to a charity on the basis that the charity was a designated beneficiary of the policy or plan was not considered a gift. ${ }^{63}$ Amazingly, it took a statutory amendment to reverse this line of authority. ${ }^{64}$ Something especially concerning, given the enormous stores of baby boomer wealth staged to flow through family trusts in future years, is the regulatory treatment of charitable donations delivered through trusts. Current regulatory practices often result in such donations going unrecognized even where they arguably achieve the very goals of donation incentives. ${ }^{65}$

How can we account for the inconsistent jurisprudence and the non-recognition of donations achieving the essential goals of donation incentives? The root cause of the problem is the pronounced tendency of the authorities to fixate on considerations lacking any apparent policy significance. Almost all manifestations of this problem stem from the authorities' tendency to focus on the legal form of donation arrangements, while ignoring or downplaying economic substance. Innumerable authorities have taken the position that the term "gift" as

\footnotetext{
${ }^{52}$ CRA Document 2000-0063095, March 29, 2001; CRA Document CPC-025, February 26, 2003; CRA document no. 9818408, September 10, 1998; CRA document no. 9415135, August 8, 1994.

${ }^{53}$ In Benquesus v. R., [2006] 3 CTC 2191 (TCC), the forgiveness of a loan owed by a charity was held to qualify as a gift. CRA has taken a somewhat different approach. See, for example, CRA document no. 2000-0063095, March 29, 2001.

${ }^{54}$ See, for example, CRA Document 2008-0267721E5, November 12, 2008; CRA Document 2003-0018595, December 2, 2003; CRA Document 2002-0163405, March 11, 2003.

${ }^{55}$ See, for example, Gaudin v. M.N.R. (1955), 55 DTC 385 (TAB); Hudson Bay Mining \& Smelting Co. v. R., [1986] 1 CTC 484 (FCTD); CRA document no. 9729915, January 20, 1998; CRA document no. 9620635, November 27, 1996; CRA document no. 9530067, January 22, 1996. Contrast with 882885 Ontario Ltd. v. R., [2007] 3 CTC 2119 (TCC).

${ }^{56}$ See, for example, Tite v. M.N.R. (1986), 86 D.T.C. 1788 (T.C.C.); CRA document no. 9600855, February 21, 1996; CRA document no. 9423317, September 13, 1994. Blended payments were also characterized as gifts (at least to the extent that they exceed the amount owing to the charity) in Jubenville v. R., [2002] 4 CTC 2058 (TCC); R. v. Zandstra, [1974] CTC 503 (FCTD); Koetsier v. M.N.R., [1974] CTC 2011 (TRB); Woolner v. R., [2000] 1 CTC 35 (FCA); McBurney v. R., [1985] 2 CTC 214. The US authorities have long since been willing to isolate the gift element of a blended payment to a charity based on the view that a gift is a transfer for inadequate consideration. See United States $\mathrm{v}$. American Bar Endowment et al., 477 US 105 (1986), at 117; Rev. rul. 67-246, 1967-2 CB 104; Rev. rul. 68-432, 1968-2 CB 104.

${ }^{57}$ For example, CRA document RC4142 "Tax Advantages of Donating to Charity" (2006) specifies at p. 3 that a gift must involve a transfer of "ownership."

${ }^{58}$ See infra notes $70-76$ and associated text dealing with voluntariness.

${ }^{59}$ See infra notes 80-87 and associated text dealing with motive.

${ }^{60}$ CRA document 2003-0014695, November 18, 2003; Registered Charities Newsletters, 18 (Spring 2004).

${ }^{61}$ See CRA document no. 9729335 , February 2, 1998.

${ }^{62}$ See CRA document no. 9800525, April 15, 1998.

${ }^{63}$ See, for example, CRA document 2002-0133545, January 16, 2003.

${ }^{64}$ See subsections 118.1(5.1)-(5.3) of the ITA.

${ }^{65}$ The CRA has expressed the view that the creation of an income interest in a trust for a charity is not a gift (see CRA document no. 9800137, April 16, 1998). Likewise, the CRA has concluded that transferring additional capital to a trust in which a charity already has a vested and indefeasible capital interest is not a gift (see CRA document 2001-0101845, January 14, 2002). For a more detailed discussion of donation arrangements involving trusts see Parachin, supra note 9 at 804-806.
} 


\section{Parachin (2012)}

used in the context of income tax law means a donation in the legal form of a gift at common law. ${ }^{66}$ The common law defines gift as a transfer of property for no consideration, i.e., for nothing in return. This understanding of gift excludes many donation arrangements whose economic substance is gift-like.

For example, the reason why donation arrangements that combine elements of gift and mutual exchange in a single transaction (e.g., sales to charities for less than fair market value or purchases from charities for over fair market value) have not consistently been recognized as gifts for tax purposes is because they are in the legal form of contracts. This is also true of arrangements where a donor designates a charity the beneficiary of a life insurance policy or RRSP-the distribution of the insurance or RRSP proceeds to the charity represents as a matter of law the fulfilment of a contract and not the delivery of a common law gift. Similarly, the reason why arrangements allowing charities the temporary use of property, incurring expenses on behalf of charities, forgiving debts owed by charities, and issuing stocks or stock options to charities have not consistently been considered gifts is because they do not entail transfers of property as required by the common law meaning of gift. All of these arrangements, and many others that have gone unrecognized under income tax law, are giftlike in economic substance but not in legal form. Recall from above, though, that economic substance is ultimately what we should be concerned about when it comes to identifying eligible donations.

In 2002 new rules-the split-receipting rules-were proposed with a view to broadening the range of donations capable of qualifying as charitable gifts for income tax purposes. ${ }^{67}$ Though these rules have never been enacted, the CRA has been applying them since they were announced by the Department of Finance. What these rules essentially provide is that a donation will not be automatically disqualified as a charitable gift for income tax purposes simply because the donor receives consideration for the donation. Rather than vitiate the donation as a gift, the presence of consideration simply reduces the value of the gift. So if a donor sells property worth $\$ 500,000$ to charity for $\$ 100,000$ of consideration, the arrangement can qualify as a $\$ 400,000$ charitable gift. The fundamental insight behind the proposed split-receipting rules is that a donation can qualify as a charitable gift for the purposes of income tax law even if it is not in the legal form of a common law gift. If the transaction confers a net benefit on a charity it can qualify as a gift, at least to the extent of the benefit conferred.

One might reasonably have anticipated that this proposed reform would sound the death knell for the various ways in which the pre split-receipting authorities prioritized legal form over economic substance. If under the split-receipting rules a common law gift is merely one of several legal forms a charitable gift may take, then surely there would no longer be any need to continue enforcing gift criteria whose historical function had been to restrict the income tax meaning of charitable gift to its narrow common law understanding as a transfer of property for no consideration. However, this is exactly what has happened resulting in a somewhat incoherent legal test for identifying charitable gifts.

Admittedly, the CRA no longer takes the categorical position that only common law gifts qualify. ${ }^{68}$ In fact, the CRA has expressly observed that "a sale of property for partial consideration can qualify as a gift." 69

\footnotetext{
${ }^{66}$ The authorities are too numerous to list. The leading case to which others often refer is R. v. Zandstra, supra note 56.

${ }^{67}$ See proposed subsections 248(30)-(32) of the ITA. For a description of the rules, see Income Tax Technical News No.

26, December 24, 2002.

${ }^{68}$ However, certain CRA publications continue to define gift solely in terms of its common law meaning (CRA document no. RC4142; 2006 CRA document 2003-0023835, November 21, 2003).

${ }^{69}$ CRA document no. 2007-0227171R3, 2007.
} 


\section{Parachin (2012)}

Nevertheless, common law gifts continue to be cast in CRA publications as the ideal benchmark. In numerous CRA publications the following statement (or some version thereof) appears: 70

In general, a "gift" for purposes of the Income Tax Act ("the Act") means a voluntary transfer of property without valuable consideration to the donor.

These publications go on to acknowledge that under the split-receipting rules it is possible "in some circumstances" for transfers for consideration to qualify. ${ }^{71} \mathrm{So}$ although gift still has its common law meaning "in some circumstances" it can also include other gift-like transactions. In other words, the proposed split-receipting rules do not establish a new paradigm for identifying charitable gift transactions so much as they codify an exception to the legal form over economic substance approach traditionally applied. The term "gift" primarily, but not exclusively, has its common law meaning.

To get a sense of the problem created, one need look no further than the criteria CRA continues to enforce as essential standards that all donations must meet in order to qualify as charitable gifts. Even under the splitreceipting rules, the CRA continues to take the position that eligible donations must meet standards pertaining to voluntariness, donor intent, and motive. None of these criteria are intrinsically relevant to whether a putative charitable gift achieves the essential goals of donation incentives. As was discussed in the section "Defining eligible donations in light of underlying theory" above, the fundamental policy issue is simply whether a donation helps to some quantifiable extent finance the delivery of charitable goods and services. A donation can meet this essential standard even if it fails the legal tests related to voluntariness, donor intent, and motive. The cases and CRA regulatory publications appear to recognize this because they do not apply the requirements for voluntariness, donor intent, and motive as though such considerations possess inherent relevance to the meaning of gift. Such criteria are instead utilized as mere policy instruments for restricting the meaning of gift to its common law meaning, which makes their continued enforcement under the split-receipting rules something of a curiosity.

Consider first the CRA's continued enforcement of the voluntariness criterion. ${ }^{72}$ The idea that a true gift is voluntary may at first appear to have nothing to do with the common law idea that a gift is a transfer for no consideration. However, a careful reading of the authorities reveals that the policy function served by the voluntariness criterion has not been to test for voluntariness per se but rather to disqualify transfers for consideration. The donation arrangements failing the voluntariness criterion include arrangements where the donor was under a legal obligation to make the donation. ${ }^{73}$ Examples consist of arrangements where the donation took the legal form of an enforceable contract between the donor and the charity, ${ }^{74}$ e.g., a sale of property to charity for less than fair market value, or even between the donor and a third party, ${ }^{75}$ (e.g., A contracts with $B$ on terms obligating $A$ to make a gift to Charity $C$ ). Notwithstanding that these arrangements

\footnotetext{
${ }^{70}$ See, for example, CRA document no. 2003-0036585, December 29, 2003; CRA document no. 2007-0228411E5,

December 19, 2007; CRA document no. T4033A, 2007; CRA document no. P113, 2007.

${ }^{71}$ Ibid.

${ }^{72}$ See, for example, CRA document 2008-0294701E5, February 20, 2009; CRA document P113, 2007; CRA document 2007-0228411E5, December 19, 2007.

${ }^{73}$ The CRA publications are too numerous to list. For a representative statement of the rule, see Interpretation Bulletin IT-110R3, "Gifts and Official Donation Receipts," June 20, 1997, at paragraph 9.

${ }^{74}$ See Tite, supra note 56; Woolner, supra note 56; Lobo v. R., [2004] 3 CTC 2507; Hudson Bay Mining, supra note 55; Commissioner of Taxation of the Commonwealth v. McPhail (1967-68), 41 ALJR 346; CRA document no. 9901985, April 19, 1999; CRA document no. 2001-0067625, March 27, 2001.

${ }^{75}$ CRA document 9729335, February 2, 1998; CRA document no. 9800525, April 15, 1998.
} 


\section{Parachin (2012)}

achieve the essential goals of donation incentives to help raise revenues for charitable institutions, they have been disqualified as gifts on the basis that their enforceable nature renders them involuntary.

Interestingly, however, not all legally enforceable donation arrangements have been disqualified as gifts on the grounds of involuntariness. That is, some donations have been upheld as voluntary gifts notwithstanding that they were made further to a legal obligation. Donations made in fulfilment of enforceable pledges ${ }^{76}$ and payments made by donors to creditors as guarantors of debts owing by charities ${ }^{77}$ have qualified as gifts notwithstanding their enforceable and thus involuntary nature. Conversely, some donation arrangements have been considered involuntary (and thus not gifts) notwithstanding that they are legally unenforceable. Examples include arrangements where charities have provided services to taxpayers subject to the taxpayers' agreement to merely consider making a donation in return. Though such donations are not legally enforceable they have been disqualified as gifts on the apparent theory that the donor's moral obligation to give rendered the donations involuntary. ${ }^{78}$

How can we account for this application of the voluntariness criterion? The key to understanding the authorities is to recognize that voluntariness is not treated as intrinsically important but rather as a way of excluding mutual exchange transactions. The authorities reveal an interesting pattern. Those arrangements failing the voluntariness requirement have tended to involve mutual exchange transactions between donors and charities, e.g., an exchange of services for a promise to consider making a donation or a sale of property for below fair market value under an enforceable contract. Conversely, those legally enforceable (and thus involuntary) arrangements qualifying as gifts have not tended to involve transactions of mutual exchange, e.g., donations made in fulfilment of legally enforceable pledges. It would appear to follow from this that the voluntariness criterion is primarily used as a mechanism to enforce the view that a gift is a transfer for no consideration. But if this is correct there is really no policy argument for continuing to enforce the voluntariness requirement given that the purpose of the split-receipting rules was to enable transfers for consideration to qualify as gifts.

Consider next the CRA's continued enforcement of the donor intent requirement. ${ }^{79}$ While the specific requirements of donor intent have never been definitively established in the tax jurisprudence, it is apparent that donor intent-like voluntariness-has been used as a tool for enforcing the common law view that a gift is a transfer for no consideration. Several authorities establish as a categorical imperative that consideration and donor intent are mutually exclusive. So even though the tax authorities have not all agreed on what donor intent specifically requires, they have tended to agree (presumably on the basis of the common law understanding of gift) that the presence of consideration vitiates donor intent. McPherson $v$. R. provides a representative statement of the principle per Little $\mathrm{J} 80$ :

There is an element of impoverishment that must be present for a transaction to be characterized as a gift. Whether this is expressed as an animus donandi, a charitable intent or an absence of consideration the core element remains the same.

\footnotetext{
${ }^{76} \mathrm{CRA}$ has taken the position in many publications that a gift in fulfilment of a pledge qualifies. See, for example, CRA document "Registered Charities: Operating a Registered Charity," December 17, 1985, paragraph 31.

${ }^{77}$ Interpretation Bulletin IT-110RD, "Gifts and Official Donation Receipts," June 20, 1997, paragraph 9.

${ }^{78}$ See, for example, McBurney v. R. [1985] 2 CTC 214 and CRA document 9901985, April 19, 1999.

${ }^{79}$ See, for example, CRA document 2008-0294701E5, February 20, 2009; CRA document P113, 2007; CRA document 2007-0228411E5, December 19, 2007.

${ }^{80}$ Supra note 46, at paragraph 20 (per Little J.) [emphasis in original].
} 


\section{Parachin (2012)}

But if this is what is meant by donor intent why continue to enforce the donor intent requirement under split-receipting rules intended to allow transfers for consideration to qualify as charitable gifts? The difficulties raised by the continued enforcement of the donor intent requirement are reflected in the following observation by the CRA. ${ }^{81}$

[A] gift is a voluntary transfer of property without valuable consideration to the donor. However, under [the split-receipting rules] a transfer of property for which the donor received an advantage will still be considered a gift for purposes of the Income Tax Act as long as we are satisfied that the transfer of property was made with the intention to make a gift. [Emphasis added]

If a gift is by definition a "transfer of property without valuable consideration," then how could a transfer for consideration ever be made with the "intention to make a gift?" Restricting the meaning of gift to transfers made with donor intent (as that term has historically been understood by tax courts) seems to run contrary to the very purpose of the split-receipting rules-to allow transfers for consideration to qualify as gifts.

Consider also CRA's ongoing enforcement of the requirement for a charitable motive. ${ }^{82} \mathrm{~A}$ number of authorities have reasoned that a donor's motive has no formal relevance to whether a donation qualifies as a gift. One of the most explicit statements of this principle was made in $R$. v. Klotz where the court observed 83 :

A charitable frame of mind is not a prerequisite to getting a charitable gift tax credit. People make charitable gifts for many reasons: tax, business, vanity, religion, social pressure. No motive vitiates the tax consequences of a charitable gift. [Emphasis added]

Further reinforcing that a donor's motive need not be charitable, a number of cases have reasoned that a donation may qualify as a gift even if the donor's primary motive was to obtain a tax advantage. ${ }^{84}$ On the other hand, several authorities have remarked that a gift must be the result of a "liberal intent" or a "detached and disinterested generosity." 85 Consistent with this, one case observed that a donor's desire to give must be the "pure moral benefit" of giving ${ }^{86}$ and in another it is said that "the motive of a disponor and the purpose of the disposition are critical matters for consideration." 87

Is it possible to reconcile the contradictory positions taken in the authorities over the issue of motive? One way to do so is to recognize that the authorities have employed the motive criterion as a way of disqualifying donation arrangements involving mutual exchanges between charities and donors. Concerns over motive tend

\footnotetext{
${ }^{81}$ CRA document no. T4033A, 2007 [emphasis added].

${ }^{82}$ See, for example, Registered Charities Newsletter No. 15, Spring, 2003; Technical News No. 26, supra note 67; CRA document CPC-024, February 26, 2003; CRA document 2007-0227171R3, December 19, 2007; and CRA document 2007-0228411E5, December 19, 2007.

${ }^{83}$ [2005] 3 CTC 78, at paragraph 25 (FCA) [emphasis added].

${ }^{84}$ See, for example, Friedberg v. R. [1992] 1 C.T.C. 1 (FCA); Whent v. R., [1996] 3 CTC 2542 (TCC); Aikman v. R., [2000] 2 CTC 2211 (TCC); Zelinski v. R. (1999), [2000] DTC 6001 (FCA); Duguay c. R., [2002] 1 CTC 8 (FCA), aff'g. [1999] 3 CTC 2432 (TCC); Langlois c. R., [2000] DTC 6612 (FCA), aff'g. [1999] 3 CTC 2589 (TCC); Côté v. R., [1999] 3 CTC 2373 (TCC); Francoeur v. R., [1993] 2 CTC 2440 (TCC).

${ }^{85}$ See, for example, Hudson Bay Mining, supra note 55; Burns v. M.N.R., [1990] 1 CTC 359 (FCA), aff'g. [1988] 1 CTC 201 (FCTD); Nadeau c. R., [2003] 2 CTC 2813; Dutil v. R. (1991), 95 DTC 281 (TCC); Tite, supra note 56; Woolner, supra note 56; McPherson, supra note 46. The CRA publications on point are too numerous to cite.

${ }^{86}$ Burns v. M.N.R., [1988] 1 CTC 201 at paragraph 28.

${ }^{87}$ Leary v. Federal Commissioner of Taxation (1980), 32 ALR 221 at 238, cited with approval in McBurney v. R., [1985] 2 CTC 214 at paragraph 11.
} 


\section{Parachin (2012)}

to be raised in the authorities where the donation arrangement involves a direct pecuniary benefit from the charity to the donor or a circular flow of cash directly between the donor and the charity or indirectly through a third party. ${ }^{88}$ Even the cases establishing that tax motivated donations can qualify as gifts have been careful to make sense of that conclusion in light of the idea that a tax benefit is not consideration. Absent consideration or a mutual exchange of some sort a selfish motive has not typically vitiated donations as gifts. ${ }^{89}$ But again, if motive is used as a proxy for consideration then what is the continued relevance of the motive test under the draft split-receipting rules?

As with any data set, there are, of course, outlier cases in which courts have broken from precedent and identified gifts on the basis of an economic substance standard. ${ }^{90}$ The difficulty with such outlier cases is that they tend to depart from precedent without acknowledging, much less explaining, the departure. So although such cases reach outcomes consistent with the tax policy behind donation incentives their primary contribution has not been to introduce greater coherence to the law but rather to further obfuscate the essential standards donations must meet in order to qualify as charitable gifts for income tax purposes.

In short, the need for reform is clear. Whereas the tax policy behind donation incentives supports a broad test based on economic substance, the authorities have tended to fixate on theoretically irrelevant considerations. Current law and regulatory practice lack a doctrinal test for identifying charitable gift transactions that is either sufficiently clear for planning purposes or consistent with underlying tax policy. While the split-receipting rules were intended to broaden the meaning of gift by enabling transfers for consideration to qualify as gifts, the CRA continues to enforce gift criteria, e.g., voluntariness, donor intent, and motive, whose historical policy function has been to disqualify as gifts transfers for consideration. It is not clear why such criteria continue to be enforced or what a taxpayer must demonstrate to reveal that such criteria are satisfied.

This state of affairs yields a number of negative consequences for the charitable sector. First, charities are losing out on potential donations. To exclude from the definition of "gift" donation arrangements that should in theory attract donation incentives removes the incentive for donors to make such donations. In some cases donors will either restructure their donations so as to qualify for donation incentives or proceed with a donation notwithstanding that it will not qualify for any donation incentives. However, inasmuch as the available empirical research supports the conclusion that donation incentives attract donations that would not otherwise get made, ${ }^{91}$ it would seem to follow that the restrictive targeting of donation incentives through an overly narrow definition of gift results in at least some lost donations.

\footnotetext{
${ }^{88}$ See, for example, Hudson Bay Mining, supra note 55; McPhail, supra note 74; Leary, ibid.; Nadeau, supra note 85; Tite, supra note 56; Woolner, supra note 56; McPherson, supra note 46.

${ }^{89}$ In Leary, supra note 87, Bowen C.J. reasoned at 223 that a "man may, by his gifts, gain fame or formal honours without losing his tax credits." The implication is that a selfish motive does not vitiate a charitable gift provided the selfish motive is non-pecuniary. See also McPhail, supra note 74, at 347 where Owen J. held that defining gift as a "present made without return of any kind" disqualifies too many transactions. In his view, only the return of a "material advantage" should disqualify a donation as a gift.

${ }^{90} \mathrm{In}$ a limited number of cases, courts have been willing to find that a gift was made even though the donation arrangement was not in the legal form of a common law gift, such as transactions that combine a gift element with a payment for goods and services. See, for example, Jubenville v. R., [2002] 4 CTC 2058 (TCC) (court isolated the gift element in a payment for adoption services in excess of fair market value), Jabs Construction Ltd. v. R., [1999] 3 CTC 2556 (TCC) (sale of property to charity on favourable terms was found to include an element of gift) and Woolner v. R., [2000] 1 CTC 35 (FCA) (that portion of private school tuition corresponding with cost of religious education qualifies as a gift).

${ }^{91}$ Supra notes $10-15$ and associated text.
} 


\section{Parachin (2012)}

Second, charities face heightened regulatory compliance costs because they are required to retain legal counsel for answers to what should (and could) be simple questions surrounding the meaning of gift. Further, the contradictions and inconsistencies in the authorities inflate legal costs because they increase the time lawyers must devote to doing opinion work in this area.

\section{New definition of "charitable donation"}

The ideal policy solution for the identified problem is to statutorily define the range of donations capable of qualifying for donation incentives. Before discussing what such a statutory definition might look like it is important to first establish why a statutory definition is necessary in the first place. Is it not possible for the CRA to administratively solve the problem by administering the proposed split-receipting rules in a way that is more consistent with underlying tax policy?

The lacklustre experience with the split-receipting rules to date owes to design flaws in the proposed rules. The sole contribution that these rules make to reforming the meaning of gift is to specify that the receipt of consideration by a donor does not "in and by itself" disqualify a donation as a gift. And even so, the proposed rules establish this principle with reference to but one of the common law gift criteria historically used by tax authorities to weed out transfers for consideration. Specifically, the draft rules imply that donor intent will not automatically be assumed absent simply because a donor receives consideration. ${ }^{92}$ No mention is made of how the presence of consideration impacts on the other criteria-voluntariness and motive-historically used to disqualify transfers for consideration or whether these other criteria should continue to be enforced. So rather than tell us what the term gift actually means, the proposed rules merely tell us that, although consideration can vitiate a donation as a gift, it is not categorically the case that gift means a transfer for no consideration. The CRA can minimize the difficulties inherent in this unstable approach through sound administrative practices, but anything less than statutory reform is mere damage control. Better to statutorily remedy the root cause of the problem, especially since the Standing Committee's study of donation incentives represents a rare opportunity for reform.

The first step in developing a statutory definition is to select an appropriate statutory moniker for eligible donations. The ongoing use of the phrase "charitable gift" should be avoided as this would invite the continued application of the very precedents that the new definition would be meant to displace. Instead, a donation should be recognized by income tax law only if meets a new statutory definition of "charitable donation." The next step is to produce a theoretically coherent and administratively practical definition of charitable donation. Ideally, the term charitable donation would be defined to include any transfer of property to or for the benefit of a charity, whether by way of common law gift, trust, sale, or any other form of transaction, provided the value of the property transferred to the charity exceeds the value of consideration received by the donor (or a party at non-arm's length to the donor). The value of the gift would reflect the net benefit conferred on the charity.

The fundamental difference between the draft split-receipting rules and the definition proposed here is that the split-receipting rules go no further than specifying that consideration is not an automatic vitiating factor. In contrast, this proposed definition of charitable donation expressly establishes economic substance as the

\footnotetext{
${ }^{92}$ Proposed subsection 248(30) of the ITA provides:

The existence of an amount of an advantage in respect of a transfer of property does not in and by itself disqualify the transfer from being a gift to a qualified donee if

a) the amount of the advantage does not exceed $80 \%$ of the fair market value of the transferred property; or

b) the transferor of the property establishes to the satisfaction of the Minister that the transfer was made with the intention to make a gift.
} 


\section{Parachin (2012)}

decisive factor for identifying eligible donations. A number of considerable advantages follow from this seemingly subtle difference. For example, the definition proposed here is a far simpler test for charities, donors, and their respective advisors to understand and apply. Rather than fixate on the legal form of donations or on poorly understood and inconsistently applied tests relating to voluntariness, donor intent, and motive, the proposed definition simply asks whether a taxpayer contributed more than he or she took back in the form of goods or services.

Not only would the proposed definition of charitable donation simplify the law, it would do a far superior job of aligning tax practice with underlying tax policy vis-à-vis charitable donations. As was discussed above, the economic substance of a donation is all that ultimately matters from a tax policy perspective. All that we need to know is whether a donation helps finance the delivery of charitable goods or services. Nevertheless, the authorities have obfuscated the law by dwelling on considerations (pertaining to legal form, motive, voluntariness,, and the like) lacking any apparent relevance to whether a donation meets this essential standard. The proposed definition of charitable donation renders such considerations irrelevant. By making economic substance a decisive consideration, the proposed definition focuses attention on the one issue that truly matters from a tax policy perspective.

The proposed definition of charitable donation can be anticipated to raise certain objections. For example, some might oppose the definition's requirement for a transfer of property on the ground that this continues the nonrecognition of donations of services. Services have been excluded for the reasons discussed above.

Another potential objection might be that the proposed definition would make it more difficult to effectively police abusive donation arrangements. Under the proposed definition, the only way to attack an abusive donation arrangement would be for regulators to conclude that the arrangement did not enrich the charitable donee to any quantifiable extent. This would reflect a departure from the historical practice of using the definition of gift as an anti-avoidance tool for attacking abusive donation schemes. For example, several authorities have concluded that participants in abusive donation schemes did not donate further to a charitable motive and thus did not make a gift. ${ }^{93}$ But if the proposed definition of charitable donation is adopted, abusive donations could no longer be denied on this basis (since eligible donations would no longer have to pass a motive test). So the question becomes whether the status quo should be preserved if only to leave open this avenue for regulating abusive donation schemes.

The problem with this reasoning is that requiring all donations to pass a generous motive test is a highly inefficient way to target abusive donation schemes. A motive test is difficult to administer (how do you accurately test for motive?), difficult to theoretically justify (it has no relevance under the frameworks discussed above in the section "Theoretical underpinnings of donation incentives"), and if consistently applied could very well disqualify non-abusive donations (not all donations inspired by selfish motives are necessarily abusive). ${ }^{94}$ The better approach would be to identify abusive donation schemes on the basis of their shared qualitative characteristics and to regulate these arrangements through dedicated anti-avoidance provisions.

\footnotetext{
${ }^{93}$ See, for example, Maréchaux v. R. [2010] 2 C.T.C. 2099. In the context of a "leveraged gift" scheme, the court concluded that no gift may be recognized by income tax law where a donation is made with the anticipation of receiving a benefit in return.

${ }^{94}$ Much of the theoretical scholarship dealing with the preferred tax treatment of charitable gifts is dismissive of the possibility that a charitable motive is even possible. See Colombo, "Marketing of Philanthropy," supra note 23. If this is correct, then what donations will pass a generous motive test?
} 


\section{Parachin (2012)}

A common feature of abusive donation arrangements is that they generate positive cash flows for donors because the value of the tax concession exceeds the donors' out of pocket costs. However, it is necessary to more specifically identify abusive donation schemes because not all profitable donations are indeed abusive. Edgar and Sandler (2003) conclude that the truly abusive donation is highly likely to be part of an actively marketed and promoted arrangement designed to create positive cash flows for donors either through inflated donation receipts for gifts-in-kind (i.e., donations of things rather than cash) or debt financed donation arrangements where the lion's share of the donations are essentially costless to donors because they are funded by third parties..$^{95} \mathrm{Admittedly}$, donations can be abusive without being actively marketed or promoted but absent the kind of widespread participation associated with marketing, such donations are unlikely to be of sufficient concern to warrant a legislative response. ${ }^{96}$ So-called "art flips" and "leveraged donation schemes" epitomize abusive donation schemes warranting a targeted legislative response.

Art flips involve professionally organized and marketed fundraising events at which donors purchase artwork at a low price and then immediately donate the artwork to charity (often without even having seen or taken possession of it). ${ }^{97}$ The artwork is appraised for gift receipting purposes at a much higher value than the donor's purchase price, though typically at less than $\$ 1,000$ in order to preserve for the donor the limited capital gains tax exemption for personal use property. ${ }^{98}$ The primary concern raised by such donations is that the appraised value is inflated and thus not a true reflection of the value of the donation. The result of the inflated donation receipt is that the combined federal and provincial tax concessions for the donation exceed the donor's cost of acquiring the art.

Leveraged donation schemes involve mass marketed donation arrangements in which the lion's share of the donations is costless to donors because they are funded by third parties. ${ }^{99}$ For example, donors might agree to make donations of a certain amount, say, $\$ 30,000$, with the understanding that further amounts will be loaned by third parties to the donors in order to top up the donation to a total amount of, say, $\$ 100,000$. The arrangements are structured such that donors are ultimately not required to pay back the loans, meaning a total donation of $\$ 100,000$ might only cost the donor $\$ 30,000$. A positive cash flow is created because the combined federal and provincial tax concessions available to donors exceed their out-of-pocket costs. The economics of these arrangements would appear to require that significant portions of the donations are circulated from the charitable donees back to the third parties financing the loans to the donors, though for obvious reasons this is not something disclosed in the marketing materials.

These donation schemes may be targeted through anti-avoidance rules applicable to donation arrangements that are (a) marketed and (b) involve either (i) the acquisition of property (such as art) with the understanding that the acquired property will be donated to charity or (ii) donations where a significant portion of the donation

\footnotetext{
${ }^{95}$ See Edgar and Sandler, supra note 43.

${ }^{96}$ Edgar and Sandler supra note 43 at 2310 observe as follows:

It is the marketing feature of donation schemes that, in fact, has caused abusive transactions to multiply to the extent that the administrative and judicial resources associated with direct valuation challenges have become severely strained, requiring an alternative response.

${ }^{97}$ See Edgar and Sandler supra note 43 at 2198.

${ }^{98}$ Subsection 46(1) of the ITA provides that capital gains tax is not payable on dispositions of appreciated personal use property provided the value of the property does not exceed $\$ 1,000$ at the time of disposition. Art flips appear to have been designed to take advantage of this rule. Donors who acquired artwork for, say, $\$ 250$, could donate it for an appraised value of $\$ 1,000$ without incurring capital gains tax. Subsection 46(5) has since established that the capital gains exemption for personal use property is unavailable where the donated property was acquired by the taxpayer as part of a marketed arrangement in which it was understood that the property would be donated.

${ }^{99}$ See Edgar and Sandler supra note 43 at 2205.
} 


\section{Parachin (2012)}

is financed on highly favourable terms to the donor. Indeed, these kinds of schemes are already being targeted through rules specifically designed to render them non-profitable for promoters and participants. ${ }^{100}$ Concerns over inflated donation receipts raised by art flips have been addressed through proposed rules designed to restrict in certain circumstances the amount for which donation receipts may be issued to the amount paid by donors for donated properties. ${ }^{101}$ Leveraged donation schemes have been attacked through proposed rules providing that a donation receipt may not be issued for any portion of a donation that was debt-financed through loans meeting certain criteria (i.e., criteria that result in the loan being essentially costless to the donor). ${ }^{102}$ The purpose of these rules is to restrict the amount for which official donation receipts may be issued for donations that are likely abusive to the amount by which donors are out-of-pocket. Since these rules speak more to the valuation of donations rather than the identification of qualifying donations, there is no reason why they could not be very effectively combined with the proposed definition of charitable donation.

Another objection to the proposed definition of charitable donation might be that, although the proposed definition remedies the speciousness of the form over substance orientation to the status quo, it introduces some significant new regulatory challenges of its own. There is some merit to this concern, especially in relation to the valuation of donations. The historical emphasis on legal form, though theoretically flawed, had the practical benefit of avoiding some very difficult valuation issues. Transactions could be disqualified as giftsthereby rendering moot the issue of valuation-simply because they were not in the legal form of common law gifts. Under the proposed definition of charitable donation it will be necessary with practically every transaction involving a charity, including a fee for charitable services rendered, to confirm whether the taxpayer contributed more than he or she took back. Some very difficult valuation issues will be raised because many of the services for which charities charge a fee are not provided generally in the market, making it difficult to determine the true economic substance of these transactions.

For example, how would regulators conclude whether a person paying tuition to an educational charity received educational services commensurate with the tuition paid? Similarly, how should donations in exchange for naming privileges be valued? It may be necessary to adopt some blunt administrative rules, such as a rule deeming that fees for charitable services correspond with the value of the services received. Such an approach has already been developed in relation to naming privileges where the CRA has somewhat surprisingly taken the position that naming privileges received by donors generally have no value. ${ }^{103}$

So the reform proposed here is not uncontroversial, nor does it provide all of the answers. Nevertheless, it focuses attention away from the theoretically irrelevant issues that have long since confused the jurisprudence and toward what ultimately matters-the economic substance of donation transactions. In this way it forces regulators to ask the right questions of putative charitable donations.

\footnotetext{
${ }^{100}$ For a discussion and critique of the rules see Edgar and Sandler supra note 43.

${ }^{101}$ See proposed subsection $248(35)$ of the ITA.

102 See proposed subsection $248(32)$ of the ITA.

${ }^{103}$ In CRA document no. 2005-0130381R3, 2005; CRA document no. 2005-0110701R3, 2005; CRA document no. 20060218471R3, 2007; CRA document no. 2003-0043013, 2003, the CRA observes that naming rights will have a nil value provided that there is no "prospective economic benefit" associated with the naming rights. Prior to the split-receipting rules, the CRA consistently observed that naming rights did not constitute consideration. See, for example, CRA document no. 9731345, February 25, 1998 and CRA document no. 9613015, September 24, 1996.
} 


\section{Parachin (2012)}

\section{Conclusion}

The test currently applied to identify what charitable donations are eligible for donation incentives under the ITA is overly restrictive and excessively complicated. It not only heightens administrative compliance costs for charities but also likely results in lost charitable donations. In addition, it undermines the tax policy objectives donation incentives are meant to achieve. Further, it is indecipherable in many respects except to those with highly specialized knowledge in the fields of property, trust, and tax law. Even to a specialized audience there are elements to the test that cannot be reconciled. Previous reform efforts-the split-receipting rules-have been unsuccessful at producing a test that is either simple to understand or attentive to underlying tax policy considerations. The ideal policy solution is for the Standing Committee on Finance to recommend the adoption a new statutory definition of "charitable donation." The proposed definition would introduce new revenue sources to charities while reducing administrative compliance costs. It would remedy significant shortcomings in current law and regulatory practice.

\section{ACKNOWLEDGEMENTS}

The author acknowledges the helpful comments and suggestions of the anonymous reviewers and the able research assistance provided by Patricia Goodman.

\section{ABOUT THE AUTHOR / L'AUTEUR}

Adam Parachin is an Associate Professor with the Faculty of Law, University of Western Ontario. Email: aparachi@uwo.ca 